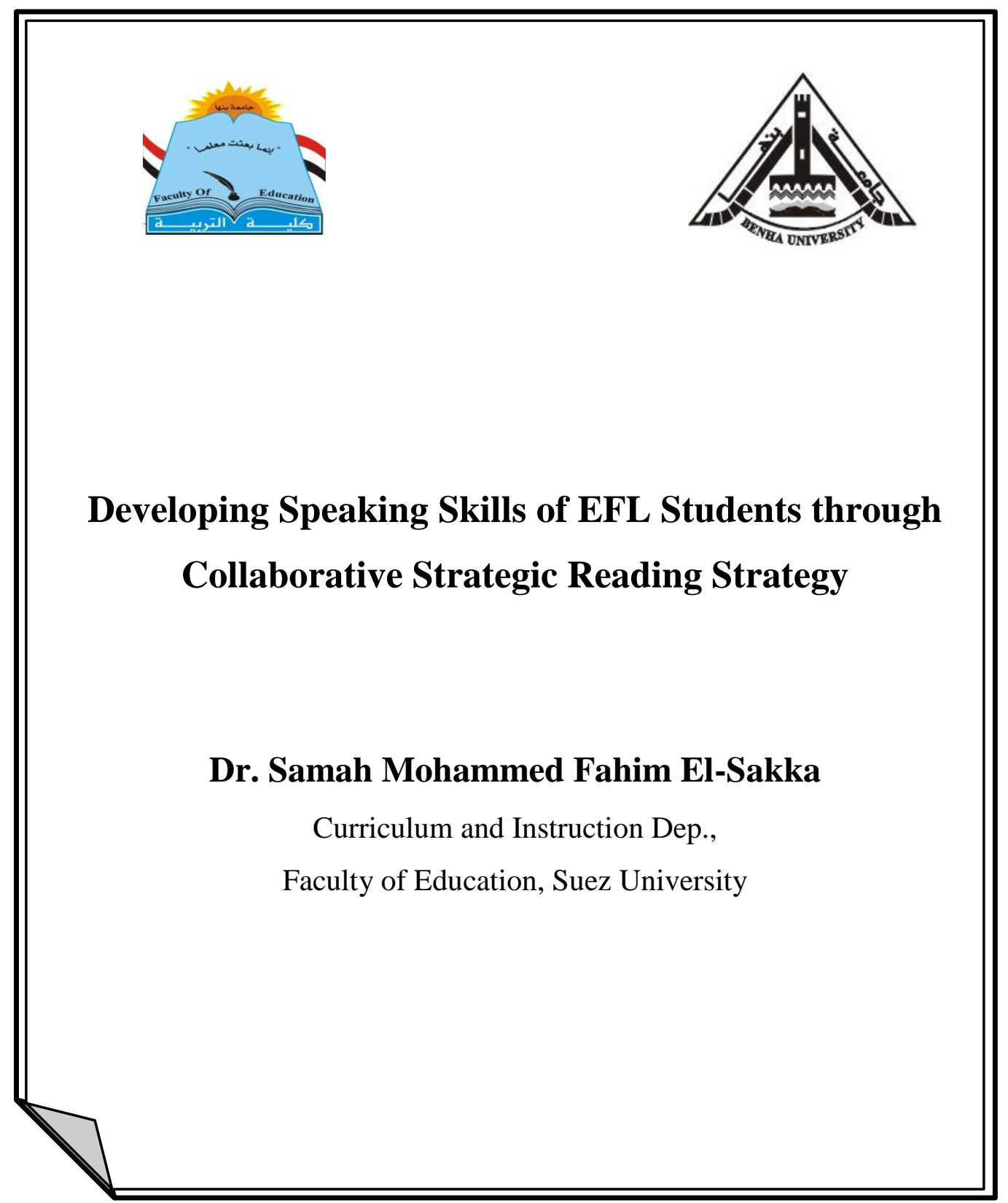




\title{
Developing Speaking Skills of EFL Students through Collaborative Strategic Reading Strategy
}

\section{Dr. Samah Mohammed Fahim El-Sakka}

Curriculum and Instruction Dep.,

Faculty of Education, Suez University

\begin{abstract}
The aim of this study was to investigate the effect of using Collaborative Strategic Reading Strategy (CSRS) on developing the speaking skills of EFL university students. The design of the study was a pre-post quasi experimental design. Instrument was a pre-post speaking test. Participants were fifty EFL freshman university students divided into two equivalent groups: control group (25 students), and experimental one (25 students). The two groups were pre-tested in the dependent variable (speaking skills). The experiment lasted for three months. During this period, the experimental group was taught using the collaborative strategic reading strategy while the control group was taught using the regular method. At the end of the experiment, the two groups were post tested. Significant differences were found between the mean scores of the experimental and the control group students' in favor of the experimental group. Also, significant differences were found between the mean scores of the pre and post test of experimental group students' in favor of the post test. It was concluded that collaborative strategic reading strategy developed the speaking skills of EFL freshman university students.
\end{abstract}

Keywords: Collaborative strategic reading, EFL freshman university students, Speaking skills. 


\section{Introduction}

One of the main aims of learning a foreign language in the $21^{\text {st }}$ century is developing speaking (Tabatabaei, Afzali, \& Mehrabi, 2015) as it has become the language of international communication as well as an integral part of everyday life (Griffiths, 2008; Luchini, 2007; Tuan \& Neomy, 2007). Therefore, it is the most demanding skill among the four language skills for both students to master and teachers to develop (Hedge, 2008; Lazaraton, 1996; Warschauer, 1996) because it provides a basis for how well learners listen, and write (Richards \& Renandya, 2002). Thus, speaking skills cannot be ignored in EFL classrooms since teachers often judge a learner's proficiency level according to how well his/her speaking performance is (Chuang, 2009, p. 72). That is why many researchers (e.g.; Glover, 2011; Burkart \& Sheppard, 2004) believe that the degree of success in language learning is measured by making a conversation in the target language.

To develop speaking, the teacher has to develop the oral interaction inside the classrooms (Nunan, 1991). Nunan (1991) states: "Speaking is the same as oral interaction which are conventional ways of presenting information, expressing our idea and thought have in our mind" (p40). Therefore, using the target language to share ideas and feelings, to express an opinion, to be understood by others, and to respond to what already has been said by others in classroom is much more important than knowing about it and its rules (Lamara, 2015). Though speaking skills contribute greatly on how students learn, EFL students often show difficulty in using English appropriately in interactions (Malmir \& Shoorcheh, 2012; Gilles \& Boyle, 2010). With the limited access to native English speakers both inside and outside EFL classrooms, teachers should - Erten and Altay (2009) believe create opportunities for developing speaking skills through using appropriate teaching strategies that provoke oral interaction. 
The researcher, as a lecturer of TEFL, noticed that EFL freshman university students in Suez Faculty of Education encountered many problems in speaking and using the target language as a means of communication during lectures. The researchers' notice was confirmed by a number of studies that investigated speaking skills at the university level (e.g., El-Sakka, 2016; Diyyab, Abdel-Haq and Aly, 2013; Hussein, 2001; and El-Koumy, 1998). Those studies revealed that EFL university students face many difficulties in their speaking skills. To ensure her remarks as well as those studies' findings, the researcher conducted a pilot study on 20 English major students (out of the sample of the study) through administering a speaking proficiency test prepared by the researcher. The results of the test revealed that most students (90\%) encountered problems in speaking fluency as well as accuracy.

EFL university students need chances to use the target language in communicating and negotiating information in a supportive, nonthreatening atmosphere (El-Sakka, 2016). That is why the researcher suggests using CSRS to develop the speaking skills of EFL students. While the effect of collaborative strategic reading on different aspects of language (e.g., reading comprehension, self-regulation, interaction patterns, general proficiency, and vocabulary) has been studied, little attention has been paid to its effect on the speaking skills of EFL students.

\section{Statement of the problem}

The problem of the present study was the low level of the speaking skills among freshman EFL university students at Suez Faculty of Education, Suez University. In an attempt to find a solution for this problem, this study suggested using collaborative strategic reading strategy to develop their speaking.

Therefore, the present study will answer the following question: 
What is the effect of using collaborative strategic reading strategy on the speaking skills of EFL freshman university students?

\section{Hypotheses of the Study}

The hypotheses of the present study were formulated as follows:

1. There would be no statistically significant difference in the control group students' mean scores on the pre and post test of speaking skills.

2. There would be no statistically significant difference in the experimental group students' mean scores on the pre and post test of speaking skills.

3. There would be no statistically significant difference in the gain score of the control group and that of the experimental group on the post test of speaking skills.

\section{Significance of the Study}

The significance of the present study lies in the following points:

1. It will shed light on the impact of collaborative strategic reading strategy on EFL students' speaking skills.

2. It is assumed that CSRS is a promising teaching strategy in combining the teaching and learning of two important skills: Reading and speaking.

3. The findings of this study will hopefully help language teachers in making the classroom environment more enjoyable and less stressful.

4. This study tries to develop speaking skills through reading which is overemphasized in the Egyptian universities.

5. It shows the positive effect of collaboration in developing speaking skills. 


\section{Delimitations of the Study}

The present study is delimited to:

1. Fifty first year English majors at Suez Faculty of Education.

2. The first term of 2016-2017 academic year.

\section{Definition of Terms}

\section{Collaborative Strategic Reading Strategy (CSRS)}

It is operationally defined as a teaching strategy that combines reciprocal teaching and cooperative learning. It starts with previewing the reading text and giving the group members' the chance to speak about their expectations concerning the reading text. Then, students move to the second stage in which they search for the clunks that cause comprehension breakdown. In groups, the students discuss those clunks and the fixing strategies that might be used in overcoming those clunks. After that the group members try to give the gist of the reading text and mention the main idea of the passage as well as the main ideas of the individual paragraphs. In the wrap up stage, the students have to summarize the reading passage in their own words. Finally, group members have to orally handle a similar topic, discuss it, ask and answer questions about it...etc.

\section{Speaking Skills}

In the present study, speaking skills were operationally defined as the progress participants achieved in their speaking as manifested by the participants' scores on the pre-post test of speaking skills devised by the researcher.

\section{Review of Related Literature}

In 1998, Klingner, Vaughn, and Schumm proposed Collaborative Strategic Reading (CSR) as an important strategy that helps students become strategic and self-regulated learners. It combines two instructional approaches: reciprocal teaching and cooperative learning (Khonamri \& Karimabadi, 2015). 


\section{The Rationale for Using CSRS}

Since the main goal of the teaching context under investigation in the present study was to enable EFL students achieve maximum oral practice in the classroom, it is assumed that CSRS results in more meaningful participation involving real communication through collaboration with peers as well as the teacher. The researcher assumes that CSRS is most beneficial in developing speaking skills of EFL students for many reasons:

1. During CSR, students become motivated to take part in the discussions about the topics that are raised by the reading texts.

2. Working cooperatively in small groups enables students to read, comprehend and speak more efficiently.

3. Open discussions about the reading topics in cooperative groups provoke students to speak in a relaxed context, free from the speaking anxiety caused by the teacher and the whole class. This, in turn, leads to an improvement and increase in speaking practices (Gillies, 2006; Altay \& Öztürk, 2004).

4. Peers are often aware of their group-mates' misunderstanding; acting as natural interlocutors, leading to a greater variety of models with whom to practice. (Gillies, 2006).

\section{Theoretical Perspectives}

In the past, skills were taught individually because it is believed that discrete skills are learned more easily and it is difficult to teach various skills simultaneously (Rigg, 1991). Therefore, the focus was on improving only one skill at a time, such as reading, or sub-skills, such as vocabulary items (Mohan, 1986 as cited in Movahed \& Karkia, 2014). Later on, practitioners and theoreticians began to understand the importance of integrating language skills in the teaching and learning process (Shen, 2003).

CSRS is based on the work of Piaget's (1965) as well as Vygotsky's (1978) theories of learning and social constructivism. 
Their theories gave much importance to the role of interaction and the use of discussions in the learning process. Vygotsky's Social Development theory (1962) gives importance to the learning contexts that give students active roles in their learning. Richards and Rodgers (2001) believe that through interacting with each other in social and pedagogical situations, learners can develop their speaking competence.

\section{Collaborative strategic reading sub-strategies}

During the past few years, a large amount of research has been done on strategy instruction in general and Collaborative Strategic Reading (CSR) in particular (Karimabadi, Khonamri, Mahdavi, 2015), as a recent approach to the teaching of reading strategies. This strategy is divided into three sub-categories i.e. before reading, during reading, and after reading strategies (Khonamri \& Karimabadi, 2015; Abidin \& Riswanto, 2012). Those three subcategories are further divided into the following four reading strategies (Zainolabidin, 2012):

1. Preview (before reading): This strategy aims at introducing the text to students, activating their background knowledge, and helping them to make predictions about the reading text. To exploit this strategy in developing speaking, the teacher provokes students to orally answer questions like: what do you already know about the topic?, What do you think you will learn about the topic when you read the passage? (Klingner \&Vahun, 1998).

2. Click \& Clunk (during reading): It is a self-monitoring strategy that controls students' understanding of the words, the concepts and the ideas of the reading text (Abidin \& Riswanto, 2012). Click refers to comprehension success while clunk refers to comprehension breakdown. To foster students to speak, the following questions could be used during that stage: What were the parts that you understood (clicks), what were the parts that were difficult to understand (clunks)? What kind of 
strategies can you use to fix the clunks? (Abidin \& Riswanto, 2012; Klingner \&Vahun, 1998).

3. Get the Gist (during reading): The researcher assumes that it is a very important stage because during this strategy students are asked to reproduce the main ideas of the passage in their own words. Thus, it is the beginning of the free production stage.

4. Wrap up (after reading): It is very important in developing the speaking skills as the students are asked to summarize orally what they have understood, and reflect on the whole process.

\section{Collaborative Strategic Reading and Speaking}

There are many factors that affect students' speaking skills inside the classrooms such as: learners' motivation to speak, the methods and materials used to provoke speaking, the classroom's atmosphere and the chances provided to learners to speak (Kosari \& Bedir, 2014). Accordingly, using collaborative strategic reading as a teaching strategy provokes oral participation at its maximum level. To develop speaking skills, the language teacher should give learners practice with fluency and accuracy, use pair-work and group-work strategies, plan discussions, and prepare learner-centered activities that involve practice of students and guidance from the teacher (Nunan, 2003). Thus, the most beneficial speaking practices are those that give students the chance to collaborate, discuss, generate questions and negotiate meaning during the oral interaction inside the class (Derakhshan, Khalili \& Beheshti, 2016; Ellis, 2003; Bygate, Skehan, \& Swain, 2001).

Based on the above, the researcher assumed that CSR incorporates all the conditions that seem to be useful in promoting speaking. Those conditions can be summarized as follows: 


\section{The Reciprocal Relationship between Reading and} Speaking

Hilferty (2000) believes that there is a reciprocal relationship between reading and speaking as both skills need the same kind of abilities in order to process the phonologically difficult materials (i.e. using the language for learning as well as communication). Chastain (1988) proposes that reading includes mental processes like those of speaking. Additionally, Lazaraton (2001) suggests that speaking is based on four main competences: grammatical competence (e.g., vocabulary, word, phonology and sentence formation); sociolinguistic competence (e.g., rules for social interaction); discourse competence (i.e. how sentences are linked together); and strategic competence (strategies used in difficult situations). Mccarthy (2000) believes those competences are significantly correlated to reading. Through reading, learners acquire vocabulary and grammar, notice how words fit together, and begin mastering the patterns of the foreign language (Azzubeir, 2015). Reading provides the suitable input and the essential vocabulary to speaking as it encourages students to use the language orally and boosts their confidence while speaking (Azzubeir, 2015). Accordingly, a good reader feels self-confident when discussing things with others. To conclude, students who read well are more likely to speak well (Azzubeir, 2015; Mart, 2012; Celce-Murica, 2001) because they apply the information they have read into authentic speaking practice that improves their speaking fluency and accuracy (Akbar, 2014; Mart, 2012; Celce-Murica, 2001).

\section{Collaboration and Speaking Skill.}

Undoubtedly, speaking is a complex skill that should be taught in groups (Celce-Murica, 2001). Oradee (2012) argues that speaking should incorporate activities in a group work 
because, as stated by Harmer (2007), pair and group work enhance the amount of student's talking time. When students interact with each other, they become better in their oral skills than those who keep silent (Khadidja, 2010). A large body of research has confirmed the positive effects of collaboration on students' speaking skills (e.g. Sühendan \& Bengü, 2014; Talebi \&Sobhani, 2012; Ning, 2011; Ning \& Hornby, 2010). Lamara (2015) believes that collaboration encourages reluctant learners to interact with others and express their points of views. It also helps the teacher observe his/her learners and evaluate their progress in the target language. Additionally, it gives learners the chance to practice their spoken language in an effective way and at the same time, gives the teacher feed-back about the learners' speaking proficiency.

In collaborative strategic reading, students interact in order to help each other accomplish the tasks and the group's shared goals. Students are required to interact verbally with one another, explain things to each other, teach others, and provide each other with help, support, and encouragement (Al-Tamimi \& Attamimi, 2014; Johnson \& Johnson, 2008). CSR provides chances for interactive dialogues among students and between teachers and students (Gersten, Fuchs, Williams, \& Baker, 2001) as well as well-constructed conversations about the content of text. Collaboration also helps learners manage speech elements such as turn-taking, rephrasing, and providing feedback (Khosravani, Khosravani \& Khoosf, 2014). It is through that collaboration that learning occurs (Foote, 2009).

In view of the above, the English language classroom should no longer be dominated by the teacher; it should be more learner-centered with the teacher acting as a facilitator. By doing so, the classroom environment becomes less stressful for the students to improve their speaking skills (Al-Tamimi \& 
Attamimi, 2014) as it creates inclusive classroom environments that meet the needs of the various levels of students as it takes the heterogeneity into consideration, encouraging peer collaboration and support (Norman, 2005). Consequently, CSR increases the time of the students' talk and decreases the time of teacher's talk inside the classroom (Mackay \& Tom, 1999).

\section{Strategic Reading and Speaking Skills}

Cabaysa and Baetiong (2010) pointed out that a considerable knowledge of learning strategies can further improve students' speaking abilities. The goal here is that the strategies will help students engage in meaningful discussions about the content they are reading (Annamma, et al., 2011). In implementing CSR, the teacher models the procedures of the strategies for the whole class using think-aloud protocols and then explains the rationale for those strategies. Then, students shift to work in cooperative, heterogeneous groups in which each student has a specific role under the guidance of the teacher (Abidin, and Riswanto, 2012).

\section{Anxiety-free Classroom and Speaking Skills}

An anxiety-free, non-threatening classroom in which learners are able to develop and maintain a pleasure-driven and interest-driven attitude to speaking is an important factor in developing speaking skills (El-Sakka, 2016 and Azzubeir, 2015). Undoubtedly, speaking is an anxiety provoking activity that makes learners worry about losing face (El-Sakka, 2016; Azzubeir, 2015).

\section{The Role of Teacher}

In CSR, the role of the teacher shifts from transmitters of knowledge to mediators, facilitators, and coachers of learning. Teachers adopting this role should maintain a safe, non-threatening and learner centered environment where students interact positively with each other. The teacher no longer measures the capacities of the 
students in terms of the final product, but he observes, monitors their oral participation, cooperation as well as performance. The teacher acts as a friend, coordinator, director, guide, counselor, and facilitator (Cowei, 1994). The teacher walks around the groups of students and monitors their progress. He/she guides the student discussions, listens to them, provides ongoing feedback, and checks understanding (Avenia, 2012; Klingner, et al. as cited in Novita, 2012).

\section{The Role of the Learner}

In CSR, learners' roles are an important aspect, because CSR works best when all the members of the group are assigned special roles to perform meaningful tasks (Alamin \& Ahmed, 2014). Possible roles include the following (Alamin \& Ahmed, 2014; Klingner et al. as cited in Novita, 2012):

1. Leader: The one who guides the group in implementing CSR. He/She guides the groups' members and tells them what to read next and what strategy to apply. Also, he/she seeks the teacher's assistance, if necessary.

2. Clunk expert: The one who tries to help the members of the group to figure out difficult concepts or words. He/she uses clunk cards to make the group aware of the steps to be followed when the group encounters comprehension breakdown.

3. Gist expert: This learner guides the group to find out the main ideas.

4. Announcer: He/she controls the process of turn taking and makes sure that each member in the group participates.

5. Encourager: This member observes the members' behavior and gives feedback. He/she praises the good behavior, encourages all group members to participate in the discussion and assist one another. Additionally, he/she evaluates the group's collaborative behavior and gives suggestions for improvement. 
6. Time keeper: The role of the time keeper is to monitor time in every stage of CSR. He/she sets the timer for each student's portion of CSR and lets the group know when it is time to move on (this role might be done by the teacher instead of students).

\section{Previous Studies}

Among various strategy-based instruction approaches, Collaborative Strategic Reading (CSR) has been the topic of different research studies. Many studies found that CSR has a positive effect on reading comprehension of EFL and ESL students (e.g., Oladele \& Oladele, 2016; Alqarni, 2015; Karabuga, 2012; Novita, 2012; Ziyaeemehr, 2012; Fan, 2010; Standish, 2005). Others such as Khonamri \& Karimabadi (2015) proved the positive impact o CSR on critical reading skills. McCown (2013) found positive effects of CSR on metacognitive awareness while Standish (2005) revealed significant effect of CSR on writing.

\section{Methodology}

\section{Design}

The design of the study was a pre-post quasi-experimental design. The researcher assigned two groups (control and experimental), selected from first year English majors, at Suez Faculty of Education, Suez University, Egypt. The two groups were first pretested in speaking using the speaking pre-test devised by the researcher. During the course of the experiment, the students in the experimental group were taught using collaborative strategic reading strategy, while the control group was taught using the regular method. At the end of the experiment, both groups were posttested using the speaking post test.

\section{Participants}

The sample of this study was a purposeful one of a limited number of participants ( $\mathrm{n}=50$ students). The participants were 
chosen from first year English majors at Suez Faculty of Education, Suez University. Their ages ranged from 17-19 years old. They were divided into two equivalent groups (control and experimental) depending on their scores in the pretest of speaking, devised by the researcher. The students in the experimental group were taught some reading texts using collaborative strategic reading strategy, while the control group students were taught the same reading passages using the traditional method of reading the texts and answering the questions.

\section{Variables of the study}

The study had one independent and one dependent variable. The independent variable of the study was collaborative strategic reading strategy. The dependent variable of the study was the speaking proficiency of EFL students. As for the other variables, they were neutralized.

\section{Materials}

Eight reading comprehension passages were chosen from different websites (see appendix). Those passages were adapted to be used as the content through which the collaborative strategic strategy presented. Each passage dealt with the four sub strategies of CSR. Tasks and activities for each passage were put to give participants maximum oral participation.

\section{Instruments}

Reviewing the question types of Test of Spoken English (TSE) tests, the researcher devised a pre-post speaking test, to measure the participants' speaking skills before and after the experiment. TSE is one of the commonly used batteries of assessment of spoken English worldwide (Marashi \& Dibah, 2013). It tests the ability of non-native speakers of English to speak effectively. The pre-post test consists of three parts. The first part is warm-up questions. The second part consists of two picture prompts and the participants are asked to tell a story about each picture. The third part is a reading passage and they 
are told that the scoring in this part will be on their pronunciation (see appendix).

To ensure the test validity, a jury of five university teachers reviewed the tests items to determine its suitability to measure the speaking proficiency of intermediate level. Furthermore, the test was administered to a pilot group ( $n=20$, out of the sample of the study). The coefficient alpha was used to calculate the reliability for each section. The coefficient alpha for the first section was0.85, for the second section was 0.88 , for the third section was 0.82 . These coefficients revealed that the overall instrument is internally consistent.

As for scoring the test, the TSE scoring manual was followed. The participants' answer tapes were scored by two raters (working independently) and the mean score of both raters was considered the participants' scores.

\section{Procedures}

Before starting the instructional sessions, the learners received two intensive orientation sessions on explaining the necessary information about CSR, as well as the four sub strategies of the CSR (preview, click and clunk, get the gist, and finally wrap up). The researcher used the direct method of explanation and modeling. Firstly, the researcher explained where, when, how, and why those strategies could be used, as well as how they could be adapted to various situations. Secondly, the researcher modeled it by giving examples and thinking aloud. Then, Students practiced the strategies under the guidance of the researcher who provided feedback, where necessary. The researcher introduced several examples to help students take control of the strategies. The researcher gradually released the responsibility for applying strategies to students. After the orientation sessions, the researcher started the treatment. The manipulation followed the following steps: 
1. Presentation stage: the researcher divided the class into small groups of five. She assigned students the following roles:

a) Leader: Leads the group by saying what strategy to apply and read the passage to his/her group.

b) Click and clunk expert: Uses fix-up cards to remind the group of the steps to follow when trying to figure out a difficult word or concept

c) Get the gist expert: has the responsibility of giving the main ideas and the supporting details.

d) Encourager: helps the leader in controlling the process, turn-taking and encouraging each member in the group to participate.
e) Summarizer: The one who wrap up the discussion and summarizes what already have done.

2. Implementation Stage: This stage was divided into four substages: (preview, click and clunk, get the gist, and wrap up).

a) Preview: The researcher started the preview strategy by asking some questions about the reading topic to brainstorm and make the participants ready to speak. The purpose of preview stage was to activate prior knowledge and promote prediction about what they read through guided speaking. So, participants talked to their groups about their ideas and their experience on the topic.

b) Click and Clunk: In their groups, students read the passages silently by themselves. Then, the leader read the text aloud to them. After reading the text, the members of the group discussed and reflected on the text collaboratively. During this time clunk expert recognized any complexity or misunderstanding in the text and wrote them in cue cards, then shared them orally with the group's members. The researcher circulated around the groups in order to monitor their speaking and provide feedback and assistance when necessary but left 
most of the discussion to the students and intervened only when they needed correction.

c) Get the gist: In the third stage, the gist expert gave the main idea and the most critical information the text was communicating. The other group members listened to him/her and made modifications if necessary. This stage was the most important part as it obligated the students to read critically.

d) Wrap up: After finishing the passage, the researcher asked the groups to briefly wrap up their discussion and thus completed the last stage of CSR; the Wrap Up. They were also asked to retell the most important points discussed in the group and write a report of that day's activity to be introduced orally in front of the class the next lecture.

As for the role of the time keeper, the researcher preferred to take that role to be in control of everything that happened in the group activities and free the participants to do the other activities.

3. Evaluation Stage: Each group discussed similar topic through interviewing each others, debating---etc.

\section{Results and discussion}

Table 1The Paired Samples t-test for the Difference in the Mean Scores of the Control Group on the Pre and Posttest of speaking skills

\begin{tabular}{|c|l|l|l|l|l|c|}
\hline Test & \multicolumn{1}{|c|}{ Mean } & $\begin{array}{l}\text { Standard } \\
\text { Deviation }\end{array}$ & $\mathrm{N}$ & $\mathrm{DF}$ & t-value & Sig. \\
\hline Pre & 15.89 & 3.2335 & 25 & 24 & $\mathbf{1 . 5 5 8}$ & 0.16 \\
\hline Post & 16.24 & 2.5304 & 25 & & & \\
\hline
\end{tabular}

As shown in Table 1, there was no statistically significant difference in the mean scores of the experimental group students and the control group students on the pretest of speaking $(\mathrm{t}=1.558 ; \mathbf{p}>$ 0.05). Therefore, the first hypothesis was accepted. Accordingly, it was concluded that students in the two groups were equivalent in their speaking skills at the beginning of the study. 
Table 2: Paired Samples t-test for the Difference in the Mean Scores of the Experimental Group on the Pre and Posttest of speaking skills

\begin{tabular}{|c|c|c|c|c|c|c|}
\hline Test & Mean & $\begin{array}{l}\text { Standard } \\
\text { Deviation }\end{array}$ & $\overline{\mathbf{N}}$ & DF & t-value & Sig. \\
\hline Pre & 20.60 & 1.96 & $\begin{array}{l}2 \\
5\end{array}$ & \multirow[b]{2}{*}{$2 \xi$} & \multirow[b]{2}{*}{19.20} & \multirow[b]{2}{*}{$0.000^{*}$} \\
\hline Post & 33.62 & 2.19 & $\begin{array}{l}3 \\
2 \\
5\end{array}$ & & & \\
\hline
\end{tabular}

As shown in table 2, paired samples $t$ - test revealed a significant difference in the mean scores between pre and post test of speaking $(\mathrm{t}=19.20, \mathrm{p}<0.05)$, in favor of the posttest. Therefore, it was concluded that using collaborative strategic reading strategy developed the speaking skills of experimental group students. In light of this statistical result, the second hypothesis was rejected.

This result can be related to various explanations. First, the collaborative nature of the CSR strategy encouraged all students to participate in discussions even the low level ones. This explanation is in accordance with Lamara's (2015) point of view who believes that collaboration encourages reluctant learners to interact with others and express their points of views. Additionally, Norman (2005) said that collaboration creates inclusive classroom environments that meet the needs of all students because it takes the heterogeneity into account, encouraging peer support and connection. Another explanation might be attributed to the non-threatening atmosphere the CSR provided. Using CSR motivated students to speak freely without language constrains. This explanation finds empirical evidence in El-Sakka's (2016) and Azzubeir's (2015) studies who found that the relaxed atmosphere motivates students to speak freely. Open discussion about the reading topics in cooperative groups motivates students to speak in an anxiety-free context that helped improve and increase speaking practices (Gillies, 2006, Altay \& Öztürk, 2004). Moreover, using collaborative strategic reading as a teaching method provokes oral 
participation at its maximum level. When students gave the chance to collaborate, discuss, generate questions and negotiate meaning during CSR (Derakhshan, Khalili \& Beheshti, 2016; Ellis, 2003; Bygate, Skehan, \& Swain, 2001) speaking skills improved. Improving selfefficacy and learners' autonomy is an additional reason behind this result. Undoubtedly, CSR develops autonomy and self-efficacy which in turn developed speaking. Generally speaking, students who think and work strategically are believed to be more autonomous and more motivated to learn and have a higher sense of self-efficacy or confidence in their own learning ability (Benson, 2003; Dam, 1995). Self-regulation through applying CSR might be another reason behind developing speaking. Applying various kinds of strategies while reading has turned students to be self-regulated learners. Selfregulation proves efficacy in improving EFL students' speaking proficiency (El-Sakka, 2016). Integrating reading and speaking skills might be a final explanation for that result. Through CSR, the participants applied the information they have read into authentic speaking practice that improved their speaking fluency and accuracy (Akbar, 2014; Mart, 2012; Celce-Murica, 2001).

Independent samples t-test was used to determine whether any change in speaking skills from pre to posttest was greater for one group rather than the other as depicted in the following table:

Table 3. Independent Samples t-test for the Difference in the Mean Gain Scores of the

Control and Experimental Groups on the Pre and Posttest of speaking skils

\begin{tabular}{|l|c|c|c|c|c|c|}
\hline \multicolumn{1}{|c|}{ Group } & N & $\begin{array}{c}\text { Mean Gain } \\
\text { Score }\end{array}$ & S D & DF & t-value & Sig. \\
\hline Control & 25 & 2.98 & 2.221 & 48 & $\mathbf{1 9 . 7 3}$ & 0.000 \\
\hline Experimental & 25 & 18.86 & 4.119 & 48 \\
\hline
\end{tabular}

As shown in Table 3, a statistically significant difference existed between the mean gain scores of the control and the experimental group students $(t=19.73, \mathrm{p}<0.05)$ in favor of the experimental group. Accordingly, the third hypothesis was rejected.

To decide the size of effect of this significant difference, the effect size is measured using Cohen's formula of pooled deviation for 
independent samples. Thus, it can be said that the difference between the mean gain score of the experimental group and that of the control group on the pretest and posttest of speaking has a large practical significance $(d=7, d>0.8)$. In other words, the collaborative strategic reading strategy yielded a large and substantial effect size. This result could be attributed to the beneficial effects of the CSR in the discussion of the second result.

Conclusion

Within the delimitations of the study as well as the statistical findings, the researcher could conclude that collaborative strategic reading was effective in developing the speaking skills of EFL university students.

\section{Recommendations:}

In light of the results of the study, the following recommendations have been formulated:

1. University instructors should reconsider their methods of teaching speaking and should be familiarized with integrating more than one skill while teaching.

2. CSR should be used in teaching speaking.

3. University students should be encouraged to be autonomous and self-regulated learners.

\section{Suggestions for further research}

During the course of the study, the need for further studies in the following areas becomes apparent:

1. The effect of using CSR on the oral communication skills of EFL university students.

2. An investigation of the attitudes of university teachers towards integrating reading with speaking.

3. Research is needed to investigate the effect of CSR on the vocabulary learning of primary stage pupils.

4. Research is needed to investigate the effect of CSR on the secondary stage students' speaking proficiency. 


\section{REFERENCES}

Abidin, M. \& Riswanto, S. (2012). Collaborative strategic reading (CSR) within cognitive and metacognitive strategies perspectives. European Journal of Business and Management, 4 (1), 61-69.

Alqarni, F. (2015). Collaborative strategic reading to enhance learners' reading comprehension in English as a foreign language. Academic Journal of $\begin{array}{llll}\text { Interdisciplinary } \quad \text { Studies, } & 4 & \text { (1), } & \text { 161-166. }\end{array}$ Doi:10.5901/ajis.2015.v4n1p161.

Alamin, A. \& Ahmed, S. (2014). Reading comprehension strategy (CSR) and learners' comprehension: A case study of FLD students. English Linguistics Research, 3 (2), 64-80. Doi:10.5430/elr.v3n2p64.

Annamma, S., Eppolito, A., Klingner, J., Boele, A., Boardman, A., \& StillmanSpisak, S. (2011). Collaborative strategic reading: Fostering success for all. Voices from the Middle, 19(2), 27-32.

Al-Tamimi, N. \& Attamimi, R. (2014). Effectiveness of cooperative learning in enhancing speaking skills and attitudes towards learning English. International Journal of Linguistics, 6 (4),27-45.

Akbar, F. (2014). The role of reading in improving speaking skill in the context of teaching English as a foreign language. International Journal of English Language \& Translation Studies, 2(4), 92-98.

Altay, M. \& Öztürk P. (2004). Understanding and overcoming student anxieties in speaking lessons. Sofia University Foreign Language Teaching Journal, 19 (1), 23-28.

Avenia, T. (2012).Computer-Assisted Collaborative Strategic Reading. Retrieved Sep $12^{\text {th }}, 2016$ from http://etec.ctlt.ubc.ca/510wiki/ComputerAssisted_Collaborative_Strategic_Reading.

Azzubeir, A. (2015). Effect of reading as a receptive skill in enhancing sudanese EFL secondary school students' oral communication (Unpublished Ph.D. ). Sudan University of Science and Technology, Sudan.

Benson, P. (2003). Learner autonomy in the classroom. In D. Nunan (Ed.), Practical English language teaching (pp. 289-308). New York: McGraw Hill.

Burkart, G. \& Sheppard, K. (2004). Content ESL across the USA: A Training Packet. A Descriptive Study of Content-ESL Practices. National Clearinghouse for English Language Acquisition. Retrieved December $12^{\text {th }}, 2016$ from http://www.ncela.gwu.edu/pubs/cal/contentesl/. 
Bygate, M.; Skehan, P. \& Swain, M. (2001). Researching pedagogic tasks, second language learning, teaching, and testing. Harlow: Longman.

Cabaysa, C. \& Baetiong, L. (2011). Language learning strategies of students at different levels of speaking proficiency. Education Quarterly, 68 (1), 1635.

Celce-Murica, M. (2001).Teaching English as a second language or foreign language (2nd ed.). New York: Newbury House.

Chastain, K. (1988). Developing Second Language Skills, Theory and Practice $\left(3^{\text {rd }}\right.$ Ed.). Diego, CA: Harcoart Brace Jovanovich.

Cowie, H. (1994). Co-operative group work: a perspective from the U.K.

International Journal of Educational Research (special issue on co-operative learning in social contexts).

Chuang, Y. Y. (2009). Foreign language speaking assessment: Taiwanese college English teachers" scoring performance in the holistic and analytic rating methods. Asian EFL Journal, 11(1), 150-173.

Dam, L. (1995). Learner Autonomy: from Theory to Classroom Practice. Dublin: Authentik

Derakhshan, A.; Khalili, A.; \& Beheshti, F. (2016). Developing EFL learner's speaking ability, accuracy and fluency. English Language and Literature Studies, 6 (2), 177-186.

Diyyab, E.A., Abdel-Haq, E.M., \& Aly, M.A.S. (2013). Using Multimedia-Based Programs for Developing Student Teachers' EFL Speaking Fluency Skills. Retrieved December $27^{\text {th }} \quad$, 2015 from http://files.eric.ed.gov/fulltext/ED539987.pdf

Ellis, R. (2003). Task-based language learning and teaching. Oxford: Oxford University Press.

El-Koumy, A. (1998). Effect of dialogue journal writing on EFL students' speaking skill. ERIC database. ED:424772

El-Sakka, S. (2016). Self regulated strategy instruction for developing speaking proficiency and reducing speaking anxiety of Egyptian university students. English Language Teaching, 9 (12), 22-33. Doi: 10.5539/elt.v9n12p22

Erten, I. \& Altay, M. (2009). The effects of task-based group activities on students' collaborative behaviours in EFL speaking classes. Journal of Theory and Practice in Education, 5 (1), 33-52.

Fan, y. c. (2010). The effect of comprehension strategy instruction on EFL learners' reading comprehension. Asian Social Science, 6 (8).19-29. 
Foote, E. (2009). Collaborative Learning in Community College. Retrieved July $20^{\text {th }}, 2016$ from http://www.ericdigests.org /1998-1/ colleges.htm>.

Gersten, R., Fuchs, L. S., Williams, J. P., \& Baker, S. (2001). Teaching reading comprehension strategies to students with learning disabilities: A review of research. Review of Educational Research, 71, 279-320.

Gillies, R. M. (2006). Teachers' and students' verbal behaviours during cooperative and small-group learning. British Journal of Educational Psychology, 76, 271-287

Gillies, R.M., \& Boyle, M. (2010). Teachers' reflections on cooperative learning: Issues of implementation. Teaching and Teacher Education, 26, 933-940.

Glover, P. (2011). Using CEFR level descriptors to raise university students' awarness of speaking skills. Language Awareness, 2(1), 33-52.

Griffiths, C. (2008). Strategies and good language learners. In C. Griffiths (Ed.), Lessons from good language learners (pp. 83-98). Cambridge: Cambridge University Press.

Harmer, J. (2007). The practice of English language teaching (4 ${ }^{\text {th }}$ ed.). Harlow, Essex: Pearson Education.

Hedge, T. (2008). Teaching and learning in the language classroom. Oxford: Oxford University Press.

Hilferty, A. (2000). The relationship between reading and speaking. National center for the study of adult learning and listening, 4 (A). Retrieved Sep.14 $4^{\text {th }}, 2016$ from http://www.ncsall.net/index.html@id=328.html.

Johnson, D., \& Johnson, R. (2002).Learning together and alone: Overview and meta-analysis.Asia Pacific Journal of Education, 22, 95-105.

Klinger, J.K., \& Vaughn, S. (1998), "Using CSR". Retrieved on Sep 16 ${ }^{\text {th }}, 2016$ from http://www.idonline.org/id in depth/teaching technique/collab reading.html [accessed on June 2010].

Klingner, J. K., Vaughn, S., \& Schumm, J. S. (1998). Collaborative strategic reading during social studies in heterogeneous fourth-grade classrooms. The Elementary School Journal, 99, 3-22. http://dx.doi.org/10.1086/461914

Karabuğaa, F. (2012). Collaborative strategic reading with adult EFL learners: Collaborative and reflective approach to reading. to çukurova University Institute of Social Sciences, Turkey.

Karimabadi, M., Khonamri, F., \& Mahdavi, O. (2015). Investigating Iranian students' attitude toward using collaborative strategic reading in their reading course. WALIA journal, 31(S3), 260-265 
Khadidja, K. (2010). The effect of classroom interaction on developing the learner's speaking skill (Unpublished M. A. thesis) . Mentouri university.

Khonamri, F. \& Karimabadi, M. (2015). Collaborative Strategic Reading and Critical Reading Ability of Intermediate Iranian Learners. Theory and Practice in Language Studies, 5 (7), 1375-1382. DOI: http://dx.doi.org/10.17507/tpls.0507.09

Kosar, G. \& Bedir, H. (2014). Strategies-based instruction: A means of improving adult EFL learner's speaking skills. International Journal of Language Academy, 2 (3), 12-26.

Khosravani, M.; Khosravani, M. \& Khoosf, S. (2014). Fostering EFL learners' speaking and listening skills via oral activities of reading short stories. International Journal of Language Learning and Applied Linguistics World (IJLLALW), 5 (1), 329-337

Lamara, A. (2015). The impact of cooperative group work in overcoming EFL students' speaking difficulties. (Unpublished Master thesis). Mohamed Kheider University of Biskra.

Lazaraton, A. (2001). Teaching Oral Skills. In M. Celce-Murcia (Ed.), Teaching English as a second foreign language. Boston: Heinle and Heinle.

Lazaraton, A. (1996). Teaching oral skills. In M. Celce-Murcia (Ed.), Teaching English as a second or foreign ortalanguage (pp. 103-115). Boston, MA: Heinle \& Heinle.

Luchini, L. P. (2007). Integrating the teaching of language as and for communication in the EFL reading class: A case study. Asian EFL Journal, 22(2), 108-121.

Mackay, H., \& Tom, A. (1999). Teaching Adults Second Language Learning. Cambridge: Cambridge University Press.

Malmir, A., \&Shoorcheh, S. (2012). An investigation of the impact of teaching critical thinking on the Iranian EFL learners' speaking skill. Journal of Language Teaching and Research, 3 (4), 608-617.

Marashi, H. \& Dibah, P. (2013). The comparative effect of using competitive and cooperative learning on the oral proficiency of Iranian introvert and extrovert EFL Learners. Journal of Language Teaching and Research, 4 (3), 545-556. Doi:10.4304/jltr.4.3.545-556

Mart, C. (2012). Developing speaking skills through reading. International Journal of English Linguistics, 2 (6), 91-96. Doi:10.5539/ijel.v2n6p91 
Maccarthy (2000). Vocabulary: Description, Acquisition and Pedagogy. Cambridge: Cambridge University Press.

McCown, M. (2013). The Effects of collaborative strategic reading on informational text comprehension and metacognitive awareness of fifth grade students (Unpublished Ph.D. dissertation). Liberty University, Lynchburg.

Movahed, R. \& Karkia, P. (2014). Reading/Listening \& the 4/3/2 on EFL Students' Speaking Skills. International Journal of Linguistics, 6 (1), 53-66.

Ning, H. (2011). Adapting cooperative learning in tertiary ELT. ELT Journal, 65(1), 60-70.

Ning H., \& Hornby, G. (2010). The effectiveness of cooperative learning in teaching English

Novita, D. (2012). The effectiveness of collaborative strategic reading(CSR) for teaching reading comprehension at muhammadiyah. Educate, 1(1), 1-26.

Norman, D. G. (2005). Using STAD in an EFL elementary school classroom in South Korea: Effects on student achievement, motivation, and attitudes toward cooperative learning. Asian EFL Journal, 35(3), 419-454.

Nunan, D. (1991). Language Teaching Methodology. London: Prentice-Hall.

Nunan, D. (2003). Practical English Language Teaching. McGraw Hill

Oladele, A.; Oladele, I. (2016). Effectiveness of collaborative strategic reading and whole language approach on reading comprehension performance of children with learning disabilities in Oyo State Nigeria Adetoun. International Journal on Language, Literature and Culture in Education. 3 (1), 1-24. DOI: https://doi.org/10.1515/llce-2016-0001.

Oradee, T. (2012). Developing speaking skills using three communicative activities (discussion,

problem-solving, and role- play). International Journal of Social Science and Humanity, 2(6), 532- 533.

Richards, J. C., \& Renandya, W. A. (2002). Methodology in language teaching: An anthology of current practice.Cambridge: Cambridge university press.

Richards, J.C \& Rodgers, T.S (2001). Approaches and Methods in Language Teaching.

Cambridge: University press.

Riggenbach, H. (1991).Toward an understanding of fluency: A microanalysis of nonnative speaker conversations. Discourse Processes, 14, 423-441. 
Shen, Y. (2003). Teaching postgraduate English as international communication. International Association of Teachers of English as a Foreign Language. News Letters, Issue 170, Dec/Jan 2003.

Standish, L. G. (2005). The effects of collaborative strategic reading and direct instruction in persuasion on sixth-grade students' persuasive writing and attitudes (Unpublished doctoral dissertation). University of Maryland.

Tabatabaei, O.; Afzali, M.; Mehrabi, M. (2015). The Effect of collaborative work on improving speaking ability and decreasing stress of Iranian EFL learners. Mediterranean Journal of Social Sciences, 6 (4). 274-280. Doi:10.5901/mjss.2015.v6n4s1p274.

Sühendan, E. R., \& Bengü, A. A. (2014). The attitudes of students towards cooperative learning in ELT classes. International Online Journal of Education and Teaching, 1(2), 31-45.

Talebi, F. \& Sobhani, A. (2012). The impacts of cooperative learning on oral proficiency, Mediterranean Journal of Social Sciences, 3(3), 75-79.

Tuan, T. A., \& Neomy, S. (2007). Investigating group planning in preparation for oral presentations. RELC Journal, 38(1), 104-124.

Vygotsky, L. S. (1962). Thought and language. Cambridge, MA: MIT Press.

Vygotsky, L. S. (1978). Mind in society: The development of higher psychological processes. Cambridge, MA: Harvard University Press.

Warschauer, M. (1996). Comparing face-to-face and electronic discussion in the second language classroom. CALICO Journal, 13(1), 7-26.

Webb, N. (1992). Testing a theoretical model of student interaction and learning in small groups. Cambridge, UK: Cambridge University Press.

Zainol Abidin, M .J. (2012). Collaborative strategic reading (CSR) within cognitive and metacognitive strategies perspectives. International Journal of Humanities and Social Science, 2 (3), 193-195.

Ziyaeemehr, Z. (2012). The efficacy of collaborative strategic reading on the reading comprehension of ESP learners. Higher Education of Social Science, 2(1), 38-42. 